\title{
Phenethyl isothiocyanate, a bioactive agent for gastrointestinal health: a review
}

\author{
Ezequiel R. Coscueta ${ }^{1, *}$, Ana Sofia Sousa ${ }^{1}$, Celso A. Reis ${ }^{2,3,4}$ and Manuela Pintado ${ }^{1}$ \\ ${ }^{1}$ Universidade Católica Portuguesa, CBQF - Centro de Biotecnologia e Química Fina - Laboratório \\ Associado, Escola Superior de Biotecnologia, Rua Diogo Botelho 1327, 4169-005 Porto, Portugal; \\ 2 i3S - Instituto de Investigação e Inovação em Saúde, Universidade do Porto, Porto, Portugal; \\ ${ }^{3}$ Institute of Molecular Pathology and Immunology of University of Porto, Ipatimup, Porto, Portugal \\ ${ }^{4}$ Medical Faculty, University of Porto, Al. Prof. Hernâni Monteiro, Porto, Portugal \\ * Correspondence: ecoscueta@porto.ucp.pt
}

\begin{abstract}
The incidence of gastrointestinal diseases (cancer in particular) has increased progressively with considerable morbidity, mortality, and a high economic impact on the healthcare system. Dietary intake of natural bioactive phytochemicals showed to have cancer-preventing and therapeutic effects. This includes the cruciferous vegetable derivative phenethyl isothiocyanate (PEITC), a bioactive compound from watercress. PEITC antioxidant, anti-inflammatory and anticancer properties are of particular importance. This review summarizes the current knowledge on the role of PEITC as a potential natural nutraceutical or an adjuvant against oxidative/inflammatoryrelated disorders in the gastrointestinal tract. We also discuss the safe and recommended dose of PEITC. Besides, we establish a framework to guide the research and development of sustainable methodologies for obtaining and stabilizing this natural nutraceutical for industrial use. This is a topic that still needs more scientific development, but with the potential to lead to a viable strategy in the prevention of cancer and other associated diseases of the gastrointestinal tract.
\end{abstract}

Keywords: gastrointestinal diseases; nutraceutical; natural anti-inflammatory; natural antioxidant; watercress

\section{Introduction}

Over time, diseases of the gastrointestinal tract (GIT) have shown a huge problem for society, affecting millions of people and rising incidence and prevalence. Gastrointestinal disorders also have a high economic impact and decreased life quality [1]. Among GIT diseases, the burden of inflammatory bowel disease (IBD) is increasing worldwide. In 2015, in the United States of America, it was found that about 3.1 million people were diagnosed with IBD [2]. This disorder is characterised by non-infectious chronic inflammation of the mucosa and conditions such as fatigue and weight loss [3]. IBDs include various illnesses, namely, Crohn's disease and ulcerative colitis, which may later progress to small intestine cancer and colorectal cancer, respectively [4]. In the last few decades, we have witnessed significant progress in cancer research, namely in its understanding, prevention and treatment. However, cancer continues to be a worldwide killer. According to the World Health Organization (WHO), in 2018, cancer was the second principal cause of death globally, with 1 in 6 deaths being caused by this pathology [5]. In fact, in a WHO statistical analysis, colorectal cancer is one of the deadliest, corresponding, annually, to 940 thousand deaths with a mortality rate above $50 \%$.

The WHO estimates that about $30 \%$ to $50 \%$ of cancers can be prevented by changing or avoiding the main risk factors. Thus, cancer prevention represents an ideal strategy to reduce the burden of this disease, while also offering a more economical treatment strategy in the long term for cancer control [5]. Epidemiological studies established a positive correlation between increased 
consumption of vegetables and reduced risk of chronic degenerative diseases. This was attributed to the wide range of phytochemicals with important physiological action properties [6,7]. Among the most promising compounds, phytochemicals from cruciferous vegetables stand out. As a clear example, a compound that is awakening a significant interest is phenethyl isothiocyanate (PEITC) that, within what has been studied so far, exhibits interesting potential bioactivities (antioxidant, antiinflammatory, anti-cancer). Indeed, this isothiocyanate is the protagonist of this review article.

Here we briefly review the current state of knowledge on the implications of PEITC for cancer prevention in the GIT. Simultaneously, we propose a framework to guide the research and development of sustainable food solutions for prophylactic action on this global health system's priority problem.

\section{What are isothiocyanates and their natural sources?}

Isothiocyanates (ITCs) are products of the natural enzymatic degradation of glucosinolates (GLSs), phytochemical molecules from cruciferous vegetables in the Brassicaceae family. Diverse plants belong to this family, including watercress, cauliflower, broccoli, and brussels sprouts, among others [8]. ITCs are characteristic for the spicy and bitter taste when consuming the plant [9]. GLSs are inert, anionic and organic compounds, characterised by a $\beta$-D-thioglucose, a sulphated oxime group $\left(\mathrm{C}=\mathrm{NOSO}_{3}{ }^{-}\right)$and a variable side chain $(-\mathrm{R})$, which will classify the GLS as aliphatic, aromatic or indole [10]. In response to mechanical or chemical stress, the glycosidic bond of the $\beta$-Dthioglucose present in GLSs is broken through the enzyme myrosinase, so this compound converts to ITCs, thiocyanates and nitriles [11]. The amount of each product formed in this reaction can vary according to specific proteins, $\mathrm{pH}$ and/or temperature [9,11]. In Fig. 1 the described process is outlined.

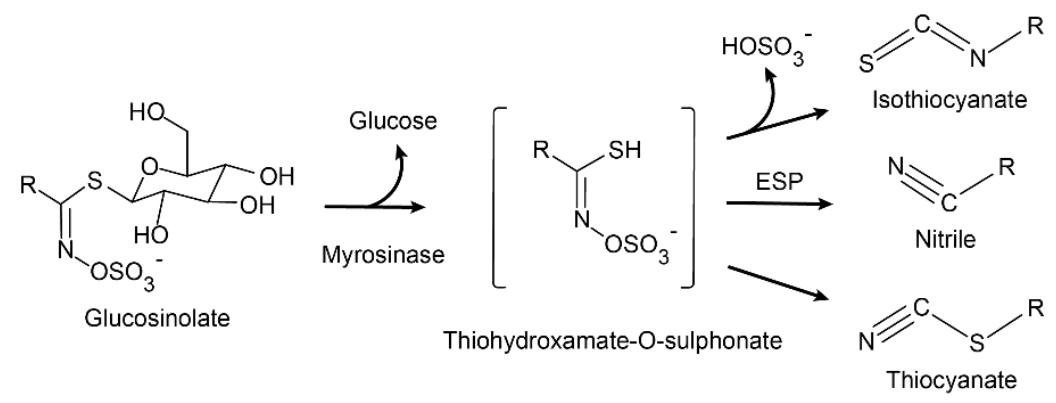

Fig. 1. GSL reaction catalysed by the enzyme myrosinase.

Regarding the chemical structure of ITCs, a highly electrophilic carbon establishes two double bonds, one with sulphur and one with nitrogen, and the radical is linked to the atom of nitrogen. This radical dictate the chemical properties of the active compound $[8,12]$.

The production of ITCs can vary depending on the conditions to which the plant is subjected, namely the temperature and $\mathrm{pH}$ at which the reaction occurs, the availability of ferrous ions and specifying proteins in the medium. Other factors will also determine the reaction's course and its final metabolites, such as plant species and age, place of cultivation, climatic conditions, storage, and processing [10].

\section{Phenylethyl Isothiocyanate}

Watercress (Nasturtium officinale) is a very accessible garden vegetable highly rich in GSLs [13]. The most characteristic GSL is gluconasturtiin, an aromatic GLS with an ethyl chain linked to benzene in its radical [14]. PEITC (Fig. 2) results from the hydrolysis of gluconasturtiin by the action of myrosinase. The final product is an ITC with a phenylethyl radical attached to a nitrogen atom [15]. 


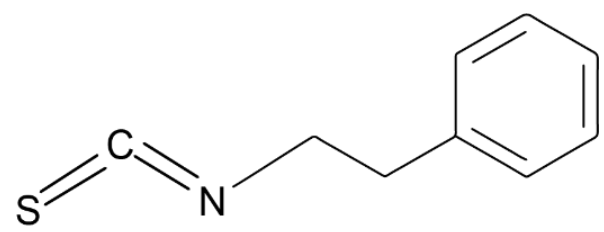

Fig. 2. Phenylethyl Isothiocyanate

PEITC is a bioactive compound capable of exercising several biological mechanisms, naturally related to protecting the plant against external factors. The plant produces PEITC in response to specific stress situations since it presents biocidal activity against various pathogens such as bacteria, fungi, insects and other pests $[8,16]$. However, the physiological properties of PEITC are not reduced only to those that it exerts in the source of origin. In this way, PEITC combines a series of biological properties with, antioxidant, anti-inflammatory and anti-cancer action. The PEITC's activity on the organism is justified by different bioactive mechanisms, namely preventing cancer through the generation of free radicals, reducing inflammation, and blocking the stages of carcinogenesis. PEITC is also known to inhibit cell proliferation, stop the cell cycle, reduction in expression of carcinogenesis or even tumour suppression with the induction of apoptosis and autophagy $[10,17,18]$.

\subsection{Antioxidant action}

Oxidative stress is an imbalance between antioxidant and oxidant species, in which the latter prevails over the others, causing an increase in reactive oxygen species (ROS) in the cell. When ROS concentration is high, damage may occur at the DNA level, increasing the carcinogenesis probability [10]. These ROS come from endogenous sources, such as reactions that occur in mitochondria and mechanisms of cellular inflammation, and exogenous sources, such as exposure to UV radiation and electrophilic molecules [19]. ROS has been implicated in the pathogenesis of diverse GIT diseases including gastroesophageal reflux disease, gastritis, enteritis, colitis and associated cancers, pancreatitis, and liver cirrhosis [20].

As a chemopreventive and antioxidant agent, PEITC may modulate the unregulated ROS concentration in cells, activating antioxidant defence mechanisms, such as increasing detox enzymes' expression to decline the ROS to basal levels necessary for cellular metabolism [16,21]. However, PEITC acts simultaneously as an oxidiser, since it has a high capacity to generate ROS and induce oxidative damage in tumour cells, so they become more sensitive to it, making it "selective" for this type of cells [12].

\subsection{Anti-inflammatory action}

In GIT, cancer development is closely dependent on energy intake and nutrient availability, but it is also characterised by low-grade inflammation (a slight but chronic increase of various inflammatory markers in the blood and organs) [22]. Inflammation is an immune response caused by several factors, such as infections or tissue damage, which can be subdivided into acute and chronic. Chronic inflammation, which results from an imbalance between pro- and anti-inflammatory cytokines, is closely associated with cancer diseases' pathogenesis [23].

Excessive expression of a pro-inflammatory factor results in damage to the epithelial barrier, initiating apoptosis of epithelial cells and secretion of chemokine. Several researchers have demonstrated the anti-inflammatory properties of PEITC, through the reduced expression of this protein by inhibiting the NF- $\kappa B$ factor transcription [12,24-26]. Two articles published by Pikarsky et al. (2004) [27] and Greten et al. (2004) [28]unequivocally demonstrated that NF- $\kappa B$ plays an essential role in developing liver and intestinal carcinogenesis, respectively. In this sense, the prevention of $\mathrm{NF}-\kappa \mathrm{B}$ activation in hepatocytes was sufficient to inhibit the development of cancers in mouse livers that were exposed to chronic liver inflammation for seven months [27]. On the other hand, classical colitis-induced carcinogenesis was abolished in mice when targeted to the NF- $\kappa \mathrm{B}$ pathway [28]. So, 
through PEITC's property of preventing the activation of NF-kB, it would inhibit cell proliferation and differentiation and promote apoptosis, in theory, would lead to cancer prevention.

\subsection{Anti-cancer action}

The consumption of the Brassicaceae family's cruciferous vegetables is associated with human health benefits as the reduced risk of chronic diseases and several types of cancer, including gastric and colon cancers $[8,29]$. Through the analysis of several studies, PEITC exhibited its anti-cancer effects by inhibiting cell proliferation by causing cell cycle arrest and inducing apoptosis in tumour cells $[10,17]$. Besides, cancer prevention comes from the effects described above, since its action reduces the risk of developing these pathologies associated with cancer.

Carcinogens are subjected to metabolism and elimination, mainly by phase I and phase II biotransformation enzymes. In general, carcinogenesis occurs due to bioactivation of carcinogens by phase I enzymes. Hence, phase I metabolism products are highly reactive intermediates that can be harmful by binding to critical macromolecules such as DNA. In contrast, phase II enzymes play an essential role in the detoxification and excretion of carcinogens from the body. PEITC is involved in the inhibition of phase I enzymes and induction of phase II, especially CYP enzymes and transferases, respectively, which can explain their chemopreventive activity [30].

Furthermore, PEITC can be used as an adjunct to increase the potential for other cancer treatments. Giallourou et al. (2019) [31] reported that the compounds extracted from watercress and PEITC improved the therapeutic results of radiotherapy, increasing the DNA damage caused by radiation in cancer cells and protecting non-tumorigenic cells from collateral damage.

However, according to epidemiological studies, the anti-cancer property of PEITC is still under investigation, so only inverse proportionality correlations have been established between the consumption of PEITC-containing vegetables and the risk of chronic diseases [10].

\section{Biocompatibility of PEITC}

Currently, clinical trials have been carried out to prove the chemopreventive properties of PEITC, for which it was necessary to analyse the toxicity in humans, to establish limit values. In a study conducted in 2018, a dose of 40 to $80 \mathrm{mg}$ of PEITC/day was administered to humans orally for 30 days, with no adverse effects [21]. However, when the dose consumed was increased to values between 120 and $160 \mathrm{mg}$ of PEITC/day, during the same experimental period, some toxicity was observed, although not lethal [21]. Other authors concluded that the acceptable daily dose is only 40 mg in humans, which is consistent with the study previously presented [32]. Thus, there is still no definitive range of concentrations for levels of toxicity in humans. However, it is known that after specific doses, PEITC can be considered toxic and interact with other drugs that are being taken simultaneously. According to Abbaoui et al. (2018) [11] PEITC despite having already demonstrated some toxic effects on organisms, to exert its therapeutic effect just non-toxic doses are necessary, so, in general, it may be safe for humans.

\section{Dosages of PEITC}

Knowing the dosages of a product is essential for its formulation since it is essential to know which quantities should be ingested for a given purpose. In this article, we try to analyse two aspects of the application in which the dose/effect is different. On the one hand, the prevention of pathologies that can culminate in more severe problems, such as cancer, and on the other hand, in the therapeutic effect of PEITC. To assess the best way forward, PEITC dosages for different cancer types were carried out on cell line. Thus, the effects caused by tumour cells when exposed to different concentrations of PEITC were studied. A range of PEITC performance values was also established, from a more preventive phase to the most curative phase, ranging from $5-30 \mu \mathrm{M}$, corresponding to $0.82-4.90$ $\mathrm{mg} / \mathrm{L}$. This information is gathered in Table 1. 
Table 1. PEITC doses in $\mu \mathrm{M}$ for different types of cancer and their mechanisms of action.

\begin{tabular}{|c|c|c|c|c|}
\hline Type of cancer & $\begin{array}{l}{[\text { PEITC] }} \\
(\mu \mathrm{M})\end{array}$ & $\begin{array}{l}{[\text { PEITC] }} \\
(\mathrm{mg} / \mathrm{L})\end{array}$ & Effect & Reference \\
\hline \multirow{7}{*}{ Colon cancer } & 10.0 & 1.63 & $\begin{array}{c}\text { Attenuation of } \\
\text { inflammation and } \\
\text { cell proliferation }\end{array}$ & $\begin{array}{c}\text { Soundararajan } \\
\text { \& Kim (2018) } \\
{[12]}\end{array}$ \\
\hline & $10.0-40.0$ & $1.63-6.53$ & $\begin{array}{l}\text { Suppression of cell } \\
\text { proliferation and loss } \\
\text { of viability of } \\
\text { tumour cells }\end{array}$ & $\begin{array}{l}\text { Chen et al. } \\
\text { (2018) [33] }\end{array}$ \\
\hline & & & $\begin{array}{l}\text { Apoptosis and anti- } \\
\text { inflammatory action }\end{array}$ & $\begin{array}{l}\text { Ramirez et al. } \\
\text { (2018) [34] }\end{array}$ \\
\hline & 10.0 & 1.63 & Tumour regression & \multirow{5}{*}{$\begin{array}{l}\text { Gupta et al. } \\
(2014)[30]\end{array}$} \\
\hline & $2.5-15.0$ & $0.41-2.45$ & $\begin{array}{l}\text { Inhibition of } \\
\text { proliferation }\end{array}$ & \\
\hline & $1.0-5.0$ & $0.16-0.82$ & Apoptosis & \\
\hline & 10.0 & 1.63 & $\begin{array}{c}\text { Anti-inflammatory } \\
\text { action }\end{array}$ & \\
\hline Gastric cancer & 1.5 & 0.24 & Apoptosis & \\
\hline \multirow[t]{2}{*}{ Cervical cancer } & $5.0-10.0$ & $0.82-1.63$ & $\begin{array}{l}\text { Cell proliferation } \\
\text { inhibition and } \\
\text { apoptosis induction }\end{array}$ & $\begin{array}{c}\text { Dai et al. (2016) } \\
\text { [17] }\end{array}$ \\
\hline & 15.0 & 2.45 & Apoptosis & $\begin{array}{l}\text { X. Wang et al. } \\
\text { (2011) [35] }\end{array}$ \\
\hline Breast cancer & $20.0-30.0$ & $3.26-4.90$ & $\begin{array}{c}\text { Inhibition of cell } \\
\text { proliferation and cell } \\
\text { cycle arrest }\end{array}$ & $\begin{array}{c}\text { Giallourou et al. } \\
\text { (2019) [31] }\end{array}$ \\
\hline Prostate Cancer & $5.0-7.5$ & $0.82-1.22$ & $\begin{array}{l}\text { Decreased } \\
\text { expression of the NF- } \\
\text { kB factor (anti- } \\
\text { inflammatory action) }\end{array}$ & \multirow{3}{*}{$\begin{array}{c}\text { Ramirez et al. } \\
\text { (2018) [34] }\end{array}$} \\
\hline Lung cancer & $12.5-20.0$ & $2.04-3.26$ & $\begin{array}{l}\text { Cell cycle arrest and } \\
\text { apoptosis }\end{array}$ & \\
\hline $\begin{array}{l}\text { Laryngeal } \\
\text { carcinoma }\end{array}$ & $0.0-10.0$ & $0.00-1.63$ & $\begin{array}{l}\text { Inhibition of cell } \\
\text { growth, cell cycle } \\
\text { arrest and apoptosis }\end{array}$ & \\
\hline \multirow{2}{*}{ Leukaemia } & 4.0 & 0.65 & $\begin{array}{l}\text { Beginning of } \\
\text { apoptosis }\end{array}$ & \multirow{2}{*}{$\begin{array}{c}\text { Gao et al. (2011) } \\
{[36]}\end{array}$} \\
\hline & $6.0-8.0$ & $0.98-1.31$ & $\begin{array}{l}\text { Significant increase } \\
\text { in apoptosis }\end{array}$ & \\
\hline
\end{tabular}

Thus, we can establish that an effective dose for prevention corresponds to a concentration of PEITC between 5 - $10 \mu \mathrm{M}$, equivalent to $0.82-1.63 \mathrm{mg} / \mathrm{L}$ since these dosages cause an antiinflammatory action and inhibition of cell proliferation. For PEITC to have a more therapeutic effect, the dosage must be higher. A concentration between $10-30 \mu \mathrm{M}$, which concerns $1.63-4.90 \mathrm{mg} / \mathrm{L}$, would be the most suitable since there is an induction of apoptosis and loss of viability for tumour cells. 
As we have already established, in this article, the analysis of the state of the art on the prophylactic and therapeutic properties of PEITC is focused on the GIT. In this sense, the most information on the chemoactive properties of PEITC comes from the study of colon cancer, being almost nil for gastric cancer. However, most of the studies are only at exploratory stages in vitro, which clarifies the need for progress to other phases to validate the findings.

\section{PEITC extraction}

We already discussed what is known so far about the potential properties of PEITC to prevent GIT disorders. PEITC is also a natural and sustainable compound since it can be extracted from watercress by-products, a raw material that is not crucial to human needs [37]. This reasoning guarantees the preservation of ecosystems, allowing the consideration of "environmentally friendly". Also, it has a very high dose-effect relationship, since for the PEITC to have a preventive action the necessary dose can be obtained through a tiny amount of watercress, which can be considered an economically viable process. Now, how can we get that PEITC?

So far, the reported work on obtaining PEITC is scarce. Furthermore, few studies apply a sustainable approach [37-40]. The applied methodologies, in general, are analytical and use polluting organic solvents that are not feasible at an industrial level, even more so when considering their use in the GIT. The few works with sustainable methodologies apply more complex and expensive techniques, and not easily scalable $[29,38,41]$ : microwave-assisted ethanol extraction, supercritical fluids. In Table 2, works with different methodologies and their advantages/disadvantages are reported. Through the analysis of Table 2, it appears that the extraction with aqueous micellar systems with non-ionic and biodegradable surfactants is the most advantageous. With this extraction method, the final product has no additives, does not contact toxic products, and is extracted sustainably. Likewise, it is a technique that needs to be further explored and optimised, to increase its yield, with, for example, the incorporation in the process of external myrosinase to increase the conversion of glucosinolates, as was done with the other methodologies. Simultaneously, by observing the Table 2, it is possible to establish a range of values for PEITC in mg per 100g of fresh watercress, between 10.5 and $68.8 \mathrm{mg}$.

\begin{tabular}{|c|c|c|c|c|}
\hline $\begin{array}{l}\text { Extraction } \\
\text { method }\end{array}$ & $\begin{array}{c}\text { Amount of } \\
\text { extracted PEITC } \\
\text { (mg PEITC/100g } \\
\text { fresh } \\
\text { watercress) }\end{array}$ & Advantages & Disadvantages & Reference \\
\hline $\begin{array}{l}\text { Aqueous } \\
\text { micellar } \\
\text { systems } \\
\text { extraction with } \\
\text { autolysis }\end{array}$ & $10.5-14.0$ & $\begin{array}{l}\text { It does not } \\
\text { involve toxic } \\
\text { solvents; } \\
\text { reduced cost; } \\
\text { sustainable; } \\
\text { stabilised } \\
\text { PEITC; "clean } \\
\text { label" product }\end{array}$ & $\begin{array}{l}\text { Depends on the } \\
\text { amount of } \\
\text { endogenous } \\
\text { myrosinase } \\
\text { present in the } \\
\text { watercress }\end{array}$ & $\begin{array}{c}\text { Coscueta et al. } \\
\text { (2020) [37] }\end{array}$ \\
\hline $\begin{array}{l}\text { Organic solvent } \\
\text { extraction }\end{array}$ & $23.3-68.8$ & $\begin{array}{l}\text { Direct and } \\
\text { ready-to-use } \\
\text { technique; } \\
\text { reduced costs }\end{array}$ & $\begin{array}{l}\text { Toxic organic } \\
\text { solvents; } \\
\text { addition of } \\
\text { external } \\
\text { myrosinase; loss } \\
\text { of active } \\
\text { compound }\end{array}$ & $\begin{array}{c}\text { Palaniswamy, } \\
\text { McAvoy, Bible, } \\
\text { \& Stuart (2003) } \\
\text { [42]; } \\
\text { Fahey, } 2006 \text { [43]; } \\
\text { Rodrigues et al. } \\
\text { (2016) [41] }\end{array}$ \\
\hline
\end{tabular}




\begin{tabular}{|c|c|c|c|c|}
\hline & & & $\begin{array}{l}\text { through } \\
\text { filtration and } \\
\text { evaporation }\end{array}$ & \\
\hline $\begin{array}{c}\text { Pressurised } \\
\text { fluid extraction }\end{array}$ & 33.5 & $\begin{array}{l}\text { A higher } \\
\text { amount of } \\
\text { extracted } \\
\text { PEITC; it does } \\
\text { not involve } \\
\text { toxic solvents; } \\
\text { preserves the } \\
\text { bioactivity of } \\
\text { the compound }\end{array}$ & $\begin{array}{l}\text { Use of high } \\
\text { pressures; } \\
\text { requires more } \\
\text { sophisticated } \\
\text { equipment }\end{array}$ & $\begin{array}{l}\text { Rodrigues et al. } \\
\qquad \begin{array}{c}\text { (2016) [41]; } \\
\text { Pereira et al. } \\
\text { (2017) [29] }\end{array}\end{array}$ \\
\hline
\end{tabular}

\section{Future Perspectives}

The bioactive properties of PEITC are still under investigation, which creates a need for clinical studies to prove the safety and effectiveness of PEITC in the body. After validating its biological properties in vivo, PEITC could achieve promising integration in the pharmaceutical industry. Thus, the use of PEITC as an adjunct to existing medication for cancer treatment would be performed to reduce the amounts of drug administered, thus reducing its side effects [44]. Even so, its performance in the GIT ailments is underexplored. Its in-depth exploration would help the development of new products for the pharmaceutical industry and the food industry with their nutraceutical lines.

Even though PEITC has great potential as a health-promoting compound, its industrial use has been limited because of its relative instability [40]. PEITC is highly reactive electrophile, susceptible to attack by nucleophilic molecules [45]. Furthermore, PEITC is a compound with low molecular weight ( $\mathrm{MW}=163.2 \mathrm{~g} / \mathrm{mol}$ ) and considerable hydrophobicity $(\log \mathrm{P}=3.47)$. Its pharmacokinetic feature includes first-order linear absorption with a high protein binding nature [46]. Therefore, its stabilisation becomes a technological challenge. An option to stabilise PEITC and even increase its bioavailability in a food matrix is micro/nanoencapsulation. However, PEITC and ITCs micro/nanoencapsulation has been poorly studied [47]. Till now, cyclodextrin was reported as a plausible carrier for ITCs [48]. Besides, PEITC was already stabilised with vegetable oils that protect non-polar ITCs from decomposition or volatilisation [40]. This opens a relevant research line aiming to identify the process conditions that could be used at an industrial level and explore or design different food and pharmaceutical matrices in which it can be incorporated. That is why the greatest opportunities for progress in the field are found in the search for alternatives and optimal stability of PEITC through different strategies that allow its use in the most diverse products. It is important to note that, in the pharmaceutical market, PEITC-based products are non-existent. Furthermore, in the nutraceutical market, only supplements can be found directly, including watercress extracts. So, after filling these gaps still existing, an innovative strategy to responding to market needs would be the development of products based on PEITC associated with its biological properties as a preventive agent or as an adjuvant to existing treatments for cancer.

Funding: This research was funded by Foundation for Science and Technology (FCT) and for Competitiveness and Internationalization Operational Program through the project n⿳0 032094 "GastroCure - Bioactive Soybean and Cruciferous extracts towards application in gastrointestinal disorders: development, characterization and delivery". 


\section{References}

1. O'Morain N, O'Morain C. The burden of digestive disease across Europe: Facts and policies. Dig Liver Dis. 2019;51(1):1-3 DOI: 10.1016/j.dld.2018.10.001.

2. Dahlhamer JM, Zammitti EP, Ward BW, Wheaton AG, Croft JB. Prevalence of Inflammatory Bowel Disease Among Adults Aged $\geq 18$ Years - United States, 2015. MMWR Morb Mortal Wkly Rep. 2016;65(42):1166-9 DOI: 10.15585/mmwr.mm6542a3.

3. Fujii T, Watanabe M. Definition and epidemiology of inflammatory bowel disease. Nihon Rinsho. 2017;75(3):357-63.

4. Lucas López R, Grande Burgos MJ, Gálvez A, Pérez Pulido R. The human gastrointestinal tract and oral microbiota in inflammatory bowel disease: a state of the science review. Vol. 125, APMIS. Blackwell Munksgaard; 2017. p. 3-10 DOI: 10.1111/apm.12609.

5. World Health Organization. Cancer. 2018.

6. Boeing H, Bechthold A, Bub A, Ellinger S, Haller D, Kroke A, et al. Critical review: Vegetables and fruit in the prevention of chronic diseases. Eur J Nutr. 2012;51(6):637-63 DOI: 10.1007/s00394-012-0380-y.

7. Pinela J, Carvalho AM, Ferreira ICFR. Watercress. In: Nutritional Composition and Antioxidant Properties of Fruits and Vegetables. Elsevier; 2020. p. 197-219 DOI: 10.1016/B978-0-12-812780-3.00012-X.

8. Palliyaguru DL, Yuan JM, Kensler TW, Fahey JW. Isothiocyanates: Translating the Power of Plants to People. Mol Nutr Food Res. 2018;62(18):1700965 DOI: 10.1002/mnfr.201700965.

9. Bell L, Oloyede OO, Lignou S, Wagstaff C, Methven L. Taste and Flavor Perceptions of Glucosinolates, Isothiocyanates, and Related Compounds. Vol. 62, Molecular Nutrition and Food Research. Wiley-VCH Verlag; 2018. p. 1700990 DOI: 10.1002/mnfr.201700990.

10. Mitsiogianni M, Koutsidis G, Mavroudis N, Trafalis DT, Botaitis S, Franco R, et al. The Role of Isothiocyanates as Cancer Chemo-Preventive, Chemo-Therapeutic and Anti-Melanoma Agents. Antioxidants. 2019;8(4):106 DOI: 10.3390/antiox8040106.

11. Abbaoui B, Lucas CR, Riedl KM, Clinton SK, Mortazavi A. Cruciferous Vegetables, Isothiocyanates and Bladder Cancer Prevention. Mol Nutr Food Res. 2018;1800079 DOI: 10.1002/mnfr.201800079.

12. Soundararajan P, Kim J. Anti-Carcinogenic Glucosinolates in Cruciferous Vegetables and Their Antagonistic Effects on Prevention of Cancers. Molecules. 2018;23(11):2983 DOI: 10.3390/molecules23112983.

13. Rubin E, Aziz ZA, Surugau N. Glucosinolates content in non-elicited plant culture, elicited plant culture and wild plant of watercress (Nasturtium officinale). Trans Sci Technol. 2018;5(1):40-5.

14. Farhana N, Aripin B, Surugau N. Effects of Temperature and $\mathrm{pH}$ on Myrosinase Activity and Gluconasturtiin Hydrolysis Products in Watercress. Trans Sci Technol. 2016;3(32):449-54.

15. National Center for Biotechnology Information (2020). PubChem Compound Summary for CID 16741, Phenethyl isothiocyanate. [Internet]. 2020.

16. Yaqoob M, Aggarwal P, Kumar M, Purandare N. ISOTHIOCYANATES ; SOURCES , PHYSIOLOGICAL FUNCTIONS. Plant Arch. 2020;20:2758-63.

17. Dai M, Wang Y, Chen C, Li F, Xiao B, Chen S, et al. Phenethyl isothiocyanate induces apoptosis and inhibits cell proliferation and invasion in Hep-2 laryngeal cancer cells. 2016;1-8 DOI: 10.3892/or.

18. Sharma A, Sharma A, Yadav P, Singh D. Isothiocyanates in Brassica: Potential Anti Cancer Agents. Asian Pac J Cancer Prev. 2016;17(9):4507-10.

19. Dayalan Naidu S, Suzuki T, Yamamoto M, Fahey JW, Dinkova-Kostova AT. Phenethyl Isothiocyanate, a Dual Activator of Transcription Factors NRF2 and HSF1. Vol. 62, Molecular Nutrition and Food 
Research. Wiley-VCH Verlag; 2018. p. 1700908 DOI: 10.1002/mnfr.201700908.

20. Kim YJ, Kim EH, Hahm KB. Oxidative stress in inflammation-based gastrointestinal tract diseases: Challenges and opportunities. J Gastroenterol Hepatol. 2012;27(6):1004-10 DOI: 10.1111/j.14401746.2012.07108.x.

21. Chikara S, Nagaprashantha LD, Singhal J, Horne D, Awasthi S, Singhal SS. Oxidative stress and dietary phytochemicals: Role in cancer chemoprevention and treatment. Vol. 413, Cancer Letters. Elsevier Ireland Ltd; 2018. p. 122-34 DOI: 10.1016/j.canlet.2017.11.002.

22. Cani PD, Jordan BF. Gut microbiota-mediated inflammation in obesity: a link with gastrointestinal cancer. Nat Rev Gastroenterol Hepatol. 2018;15(11):671-82 DOI: 10.1038/s41575-018-0025-6.

23. Mori N, Shimazu T, Charvat H, Mutoh M, Sawada N, Iwasaki M, et al. Cruciferous vegetable intake and mortality in middle-aged adults: A prospective cohort study. Clin Nutr. 2019;38(2):631-43 DOI: 10.1016/j.clnu.2018.04.012.

24. Debnath T, Kim DH, Lim BO. Natural products as a source of anti-inflammatory agents associated with inflammatory bowel disease. Vol. 18, Molecules. Multidisciplinary Digital Publishing Institute; 2013. p. 7253-70 DOI: 10.3390/molecules18067253.

25. Moon PD, Kim HM. Anti-inflammatory effect of phenethyl isothiocyanate, an active ingredient of Raphanus sativus Linne. Food Chem. 2012;131(4):1332-9 DOI: 10.1016/j.foodchem.2011.09.127.

26. Taniguchi K, Karin M. NF-B, inflammation, immunity and cancer: Coming of age [Internet]. Vol. 18, Nature Reviews Immunology. Nature Publishing Group; 2018. p. 309-24 DOI: 10.1038/nri.2017.142.

27. Pikarsky E, Porat RM, Stein I, Abramovitch R, Amit S, Kasem S, et al. NF- $\kappa$ B functions as a tumour promoter in inflammation-associated cancer. Nature. 2004;431(7007):461-6 DOI: 10.1038/nature02924.

28. Greten FR, Eckmann L, Greten TF, Park JM, Li ZW, Egan LJ, et al. IKK $\beta$ links inflammation and tumorigenesis in a mouse model of colitis-associated cancer. Cell. 2004;118(3):285-96 DOI: 10.1016/j.cell.2004.07.013.

29. Pereira L, Silva P, Duarte M, Rodrigues L, Duarte C, Albuquerque C, et al. Targeting Colorectal Cancer Proliferation, Stemness and Metastatic Potential Using Brassicaceae Extracts Enriched in Isothiocyanates: A 3D Cell Model-Based Study. Nutrients. 2017;9(4):368 DOI: 10.3390/nu9040368.

30. Gupta P, Wright SE, Kim SH, Srivastava SK. Phenethyl isothiocyanate: A comprehensive review of anticancer mechanisms. Biochim Biophys Acta - Rev Cancer. 2014;1846(2):405-24 DOI: 10.1016/j.bbcan.2014.08.003.

31. Giallourou NS, Rowland IR, Rothwell SD, Packham G, Commane DM, Swann JR. Metabolic targets of watercress and PEITC in MCF-7 and MCF-10A cells explain differential sensitisation responses to ionising radiation. Eur J Nutr. 2019;58(6):2377-91 DOI: 10.1007/s00394-018-1789-8.

32. Lam-Ubol A, Fitzgerald AL, Ritdej A, Phonyiam T, Zhang H, Myers JN, et al. Sensory acceptable equivalent doses of $\beta$-phenylethyl isothiocyanate (PEITC) induce cell cycle arrest and retard the growth of p53 mutated oral cancer in vitro and in vivo. Food Funct. 2018;9(7):3640-56 DOI: 10.1039/c8fo00865e.

33. Chen Y, Li Y, Wang XXX qi X qian, Meng Y, Zhang Q, Zhu J yun, et al. Phenethyl isothiocyanate inhibits colorectal cancer stem cells by suppressing Wnt/ $\beta$-catenin pathway. Phyther Res. 2018;32(12):2447-55 DOI: $10.1002 /$ ptr.6183.

34. Ramirez CN, Li W, Zhang C, Wu R, Su S, Wang C, et al. In Vitro-In Vivo Dose Response of Ursolic Acid, Sulforaphane, PEITC, and Curcumin in Cancer Prevention. AAPS J. 2018;20(1):19 DOI: 10.1208/s12248017-0177-2.

35. Wang X, Govind S, Sajankila SP, Mi L, Roy R, Chung FL. Phenethyl isothiocyanate sensitizes human 
cervical cancer cells to apoptosis induced by cisplatin. Mol Nutr Food Res. 2011;55(10):1572-81 DOI: 10.1002/mnfr.201000560.

36. Gao N, Budhraja A, Cheng S, Liu EH, Chen J, Yang Z, et al. Phenethyl isothiocyanate exhibits antileukemic activity in vitro and in vivo by inactivation of Akt and activation of JNK pathways. Cell Death Dis. 2011;2(4):1-9 DOI: 10.1038/cddis.2011.22.

37. Coscueta ER, Reis CA, Pintado M. Phenylethyl Isothiocyanate Extracted from Watercress By-Products with Aqueous Micellar Systems: Development and Optimisation. Antioxidants. 2020;9(698):1-11 DOI: 10.3390/antiox9080698.

38. Tanongkankit Y, Sablani SS, Chiewchan N, Devahastin S. Microwave-assisted extraction of sulforaphane from white cabbages: Effects of extraction condition, solvent and sample pretreatment. J Food Eng. 2013;117(1):151-7 DOI: 10.1016/j.jfoodeng.2013.02.011.

39. Fusari CM, Ramirez DA, Camargo AB. Simplified analytical methodology for glucosinolate hydrolysis products: a miniaturized extraction technique and multivariate optimization. Anal Methods. 2019;11(3):309-16 DOI: 10.1039/C8AY02442A.

40. Pusateri DJ, Kizer TR, Lowry AN. Extraction of non-polar isothiocyanates from plants. United States; US006824796B2, 2004.

41. Rodrigues L, Silva I, Poejo J, Serra AT, Matias AA, Simplício AL, et al. Recovery of antioxidant and antiproliferative compounds from watercress using pressurized fluid extraction. RSC Adv. 2016;6(37):30905-18 DOI: 10.1039/C5RA28068K.

42. Palaniswamy UR, McAvoy RJ, Bible BB, Stuart JD. Ontogenic variations of ascorbic acid and phenethyl isothiocyanate concentrations in watercress (Nasturtium officinale R.Br.) leaves. J Agric Food Chem. 2003;51(18):5504-9 DOI: 10.1021/jf034268w.

43. Fahey JW. Method of extraction of isothiocyanates into oil from glucosinolate-containing plants and method of producing products with oil containing isothiocyanates extracted from glucosinolatecontaining plants. United States; US 20060127996A1, 2006.

44. Wang J, Luo B, Li X, Lu W, Yang J, Hu Y, et al. Inhibition of cancer growth in vitro and in vivo by a novel ROS-modulating agent with ability to eliminate stem-like cancer cells. Cell Death Dis. 2017;8(6):e2887 DOI: 10.1038/cddis.2017.272.

45. Kala C, Salman Ali S, Ahmad N, Jamal Gilani S, Ali Khan N. Isothiocyanates: a Review. Res J Pharmacogn. 2018;5(2):71-89 DOI: 10.22127/RJP.2018.58511.

46. Mohanty S, Sahoo AK, Konkimalla VB, Pal A, Si SC. Naringin in combination with isothiocyanates as liposomal formulations potentiates the anti-inflammatory activity in different acute and chronic animal models of rheumatoid arthritis. ACS Omega. 2020;5(43):28319-32 DOI: 10.1021/acsomega.0c04300.

47. Zambrano V, Bustos R, Mahn A. Insights about stabilization of sulforaphane through microencapsulation. Heliyon. 2019;5(11) DOI: 10.1016/j.heliyon.2019.e02951.

48. Dagan ID, Frisbee AR, Newsome PW, Baudet MP. Stabilized sulforaphane. Vol. 1. United States; US007879822B2, 2011. p. 0-4 DOI: 10.1016/j.(73). 